\title{
EFFECT OF SOIL MEDIA, IRRIGATION INTERVALS AND NPK FERTILIZATION ON VEGETATIVE GROWTH OF CONOCARPUS TRANSPLANTS
}

Abdalla, M. Y. A.; M. N. Sharaf El-Din; A. M. Hamza and A. A. Helaly

Veget. and Flor. Dept., Fac. Of Agric., Mansoura Univ.

\begin{abstract}
This study aimed to investigate the effect of three soil media, three irrigation intervals, three NPK fertilization rates and their interactions on the growth and development of Conocarpus erectus tree as a new plant to the Egyptian environment. This research was carried out during the two successive seasons of $2004-2005$ and $2005-2006$.

The obtained results showed significant differences in some investigated characteristics. Clayey soil significantly gave the greatest value of plant height, number of branches per plant but had non significant effect on chlorophyll pigments content. Use of 10 or 15 days irrigation intervals significantly had an effect on plant height, number of branches per plant and chlorophyll pigments content. The addition of NPK at a rate of 5 or $10 \mathrm{gm} /$ plant resulted in significant increase of plant height and number of branches per plant while had non significant effects on chlorophyll pigments content. The interaction treatments showed that generally, clayey medium, 10 or 15 days irrigation intervals and 5 or $10 \mathrm{gm} \mathrm{NPK/plant} \mathrm{significantly} \mathrm{increased} \mathrm{the}$ values of plant height while, the mixture medium and 10 or 15 days intervals and mostly $5 \mathrm{gm} \mathrm{NPK/} \mathrm{plant} \mathrm{significantly} \mathrm{affected} \mathrm{the} \mathrm{value} \mathrm{of} \mathrm{number} \mathrm{of} \mathrm{branches/} \mathrm{plant.}$ Results of interaction showed also that clayey medium with 5 days irrigation intervals and $10 \mathrm{gm} \mathrm{NPK/} \mathrm{plant} \mathrm{significantly} \mathrm{increased} \mathrm{the} \mathrm{chlorophyll} \mathrm{pigments} \mathrm{content.} \mathrm{Clayey}$ soil irrigated every 15 days and fertilized with $5 \mathrm{gm} \mathrm{NPK/plant} \mathrm{significantly} \mathrm{increased}$ the stem diameter when compared with other treatments. On the other hand, dry matter percentage was significantly increased by the use of mixture medium (clay + sand), 5 days irrigation interval and $10 \mathrm{gm} \mathrm{NPK/plant.}$
\end{abstract}

\section{INTRODUCTION}

Conocarpus erectus, L. (Button wood) belongs to the family Combretaceae native to Bermuda, both coasts of Southern Florida, the Bahamas, the West Indies, both coasts of Mexico, Central America and South America. It is also native to coastal areas of tropical West Africa (Little and Wadsworth 1964 and Howard 1989). This tree is highly tolerant to full sun, sandy soils, salty conditions, compacted soils, air pollution, poor drainage, and drought. It has a medium growth rate and may live for several decades (Gilman and Watson 1993). Button wood has several ecological benefits and industrial uses that the wood was formerly used as fire wood, cabinets; it is difficult to work but takes a smooth finish. It is also reported to be good for smoking meat and fish as it burns very hot and slowly; it also makes high quality charcoal (Gilman and Watson 1993).

Extracts of the bark are used to treat bleeding gums, vaginal bleeding, colic, and skin ulcers (Liogier, 1990). Buttonwood is used also as ornamental tree or shrub and in bonsai. Buttonwood trees are tough and long-lasting in the landscape. It is used for seaside plantings, as a hedge; shade tree, residential street tree, buffer strips around parking lots, specimen, 
side walk cut out (tree pit), median strip planting in the high way; $\ldots$ etc (Gilman and Watson 1993). Generally, the growth and development of ornamental plants may be affected by many factors, i.e. soil, fertilizers, irrigation, climatic factors,... etc. Soils mainly have an important role in the growth and development of any plant according to their physical and chemical properties. They affect root growth, water availability, elements supply... etc. There is a typical kind of suitable soil for every plant according to its requirements. This can be known by planting it in different types of soil. The amount of water supplied and the watering intervals are very important too.

Fertilizers also have a great effect on the vegetative phases of plant growth Conocarpus erectus L. was imported to Egypt lately from Gulf area especially from Kuwait. It was important to investigate the possibility of planting it under local conditions and to study its development under the Egyptian conditions in different types of soil, watering intervals and fertilization doses.

\section{MATERIALS AND METHODS}

This study was carried out in Belqas region at Dakahlia Governorate from $15^{\text {th }}$ September 2004 till end of October 2006 using $10 \mathrm{~cm}$ seedlings.

\section{Plant materials}

Seedlings were planted in $40 \mathrm{~cm}$ diameter plastic pots filled with the tested culture media. Each treatment was represented with three replicates randomly distributed and each replicate included four plants.

\section{The tested culture media}

The basic ingredients of the tested culture media were clay and sand. The clay was brought from Belqas City while the sand was obtained from Kalabsho. The first soil was clay (medium 1) and the second one was sand (medium 2). The third soil mixture (medium 3 ) was prepared from clay and sand $(1: 1 \mathrm{v} / \mathrm{v})$. Table $(A)$ shows mechanical and chemical properties of the tested soils at the beginning of this experiment. The mechanical analysis was carried out to determine the particle size distribution of the tested soils using the international Pipette Method as described by Piper (1950). Some chemical analysis such $\mathrm{pH}$ value and electric conductivity (E.C. ds $/ \mathrm{m}$ ) were measured as described by Jackson (1967). Soluble cations and anions were determined in the soil paste extract according to Richard (1954).

Table (A): Mechanical and chemical analysis of the studied soils

\begin{tabular}{|c|c|c|c|c|c|c|c|c|c|c|}
\hline \multirow[b]{2}{*}{ Medium } & \multicolumn{10}{|c|}{ Mechanical properties } \\
\hline & \multicolumn{2}{|c|}{$\begin{array}{c}\text { Coarse sand } \\
(\%)\end{array}$} & $\begin{array}{c}\text { Fine } \\
\text { sand } \\
(\%)\end{array}$ & $\begin{array}{l}\text { Silt } \\
(\%)\end{array}$ & $\begin{array}{l}\text { Clay } \\
(\%)\end{array}$ & \multicolumn{2}{|c|}{ Texture } & $\begin{array}{c}\mathrm{CaCo}_{3} \\
(\%)\end{array}$ & $\begin{array}{c}M \\
(\%)\end{array}$ & $\begin{array}{l}\text { SP } \\
(\%)\end{array}$ \\
\hline Sand & \multicolumn{2}{|c|}{7.6} & 82.9 & 6.4 & 3.1 & \multicolumn{2}{|c|}{ Sandy } & 1.3 & 0.16 & 27 \\
\hline Clay & \multicolumn{2}{|c|}{1.3} & 24.8 & 22.6 & 51.3 & \multicolumn{2}{|c|}{ Clayey } & 2.7 & 2.10 & 68 \\
\hline \multirow[t]{4}{*}{ Clay+sand } & \multicolumn{2}{|c|}{4.1} & 60.3 & 25.7 & 9.9 & \multicolumn{2}{|c|}{ Sandy loam } & 2.1 & 1.45 & 38 \\
\hline & \multicolumn{10}{|c|}{ Chemical properties } \\
\hline & \multicolumn{4}{|c|}{ Cations (meq/100 gm soil) } & \multicolumn{4}{|c|}{ Anions (meq/100 soil) } & \multirow{2}{*}{$\mathrm{pH}$} & \multirow{2}{*}{$\begin{array}{l}\text { E.C. } \\
\text { ds/m }\end{array}$} \\
\hline & $\mathrm{Ca}^{++}$ & $\mathrm{Mg}^{++}$ & $\mathrm{Na}^{+}$ & $\mathrm{K}^{+}$ & $\mathrm{CO}_{3} \cdots$ & $\mathrm{HCO}_{3}^{-}$ & $\mathrm{Cl}^{-}$ & $\mathrm{SO}_{4} \cdots$ & & \\
\hline Sand & 0.98 & 0.66 & 1.95 & 0.09 & 0.00 & 0.95 & 0.89 & 1.84 & 8.1 & 0.72 \\
\hline Clay & 3.65 & 1.72 & 4.12 & 0.05 & 0.00 & 2.30 & 3.92 & 3.32 & 7.9 & 1.86 \\
\hline Clay+sand & 1.02 & 0.82 & 3.12 & 0.04 & 0.00 & 1.44 & 0.78 & 2.78 & 8.0 & 0.98 \\
\hline
\end{tabular}




\section{Water application treatments:}

After planting, all plants were saturated immediately with water and re-irrigated after five days. The irrigation of the tested plants was followed with a half of the field capacity at three different irrigation intervals. A one third of replicates was irrigated once every 5 days, the second third every 10 days and the last every 15 days.

\section{Fertilization treatments:}

Three levels of NPK fertilizer were used in this experiment. The first treatment (control) received no NPK fertilizer. The second treatment received $5 \mathrm{gm} \mathrm{NPK} /$ pot. The third treatment received $10 \mathrm{gm} \mathrm{NPK/pot.}$

NPK fertilizer was applied three times during this experiment, starting 6 months after planting on March $15^{\text {th }}$, and all three months interval later on June $15^{\text {th }}$ and September, $15^{\text {th }}$.

\section{Measurements of the experiment:}

The growth and development of the tested plants along this experiment was estimated by using the following measurements:

1- Plant height $(\mathrm{cm})$ : Height of plants from soil surface to the top was determined one month after each application of fertilizer.

2- Number of branches per plant: It was calculated one month after each fertilization.

3- Stem diameter $(\mathrm{mm})$ was measured $10 \mathrm{~cm}$ above the soil surface.

4- Dry matter (\%) was determined by drying vegetative samples at $70^{\circ} \mathrm{C}$ till a constant weight.

5- Chlorophyll pigments: Chl. a and Chl. b in the tested plants were estimated at the end of the experiment for each treatment directly after cutting the fresh plant leaf samples using the method described

\section{Statistical analysis} by Moran (1982).

The layout of the experiment was the randomized complete split spilt block design according to Snedecor and Cochran (1980). Soil types occupied the main plots, the subplots were devoted for the irrigation intervals treatments, whereas, the sub subplots were devoted for the different fertilization rates treatments. Means were compared using the new L.S.D. method at $5 \%$ level of significance.

\section{RESULTS AND DISCUSSION}

\section{Effect of soil type, irrigation intervals and fertilization rate on plant height of Conocarpus erectus}

\subsection{Effect of soil type:}

It was observed from data in Table (1) that using clay as a growing medium significantly gave the tallest plants as it was $49.15 \mathrm{~cm}$ in April 2005 and $50.33 \mathrm{~cm}$ in April 2006 when compared with sand + clay mixture as it was $45.30 \mathrm{~cm}$ and $48.07 \mathrm{~cm}$ in order for the two dates while the lowest value was gained from the sandy medium in the both seasons as it was $36.22 \mathrm{~cm}$ and $37.59 \mathrm{~cm}$ for April 2005 and April 2006, respectively. 
Abdalla, M. Y. A. et al.

Similar results were obtained on July 2005 and July 2006 since it was clear that clayey medium significantly gave the highest value of plant height $(108.74 \mathrm{~cm})$ in July 2005 and in July $2006(110.82 \mathrm{~cm})$ followed by sand + clay mixture $(97.33 \mathrm{~cm})$ and $(94.74 \mathrm{~cm})$ while, the sand medium gave 71.48 $\mathrm{cm}$ in each date.

In the same trend, using clayey medium significantly gave the greatest plant height values in October $2005(185.59 \mathrm{~cm})$ and in October $2006(178.96 \mathrm{~cm})$. The lowest values were gained from sand medium as it gave $106.89 \mathrm{~cm}$ and $109.11 \mathrm{~cm}$, respectively while the sand + clay mixture gave $167.93 \mathrm{~cm}$ in October 2005 and $162.48 \mathrm{~cm}$ in October 2006.

The previous results clearly show that at all dates in the two seasons, there were significant differences in plant height values among the three used media. This may be due to the ability of clayey soil to hold water and nutrients which reflect on plant growth. These results are in agreement with Pritchett and Fisher (1987) who mentioned that the greater the clay content and /or organic matter content, the greater the CEC (Cations Exchange Capacity). The types of clay minerals produced from weathering greatly influence their nutrient storage capability.

Table (1): Effect of soil type, irrigation intervals and NPK fertilizers rate on plant height $(\mathrm{cm})$ of Conocarpus erectus in two seasons

\begin{tabular}{|c|c|c|c|c|c|c|c|}
\hline \multirow{2}{*}{\multicolumn{2}{|c|}{ Treatments }} & \multicolumn{2}{|c|}{ April } & \multicolumn{2}{|c|}{ July } & \multicolumn{2}{|c|}{ October } \\
\hline & & 2005 & 2006 & 2005 & 2006 & 2005 & 2006 \\
\hline \multirow{4}{*}{$\begin{array}{l}\text { Soil type } \\
\text { (A) }\end{array}$} & Sand & 36.22 & 37.59 & 71.48 & 71.48 & 106.89 & 109.11 \\
\hline & Clay & 49.15 & 50.33 & 108.74 & 110.82 & 185.59 & 178.96 \\
\hline & Sand+ clay & 45.30 & 48.07 & 97.33 & 94.74 & 167.39 & 162.48 \\
\hline & L.S.D. 5\% & 1.13 & 1.94 & 2.07 & 2.32 & 1.70 & 2.47 \\
\hline \multirow{4}{*}{$\begin{array}{l}\text { Irrigation } \\
\text { intervals } \\
\text { (B) }\end{array}$} & 5 days & 36.67 & 36.11 & 84.30 & 81.56 & 136.11 & 132.22 \\
\hline & 10 days & 47.60 & 49.11 & 95.33 & 98.52 & 162.04 & 159.48 \\
\hline & 15 days & 46.41 & 50.78 & 97.93 & 96.96 & 162.26 & 158.85 \\
\hline & L.S.D. 5\% & 1.96 & 2.05 & 2.40 & 2.14 & 2.38 & 2.61 \\
\hline \multirow{4}{*}{$\begin{array}{c}\text { Fertilization } \\
\text { rate } \\
\text { (C) }\end{array}$} & $0.0 \mathrm{gm}$ & 36.96 & 37.52 & 68.04 & 68.04 & 128.48 & 126.33 \\
\hline & $5.0 \mathrm{gm}$ & 46.89 & 51.48 & 100.22 & 102.85 & 156.63 & 155.85 \\
\hline & $10.0 \mathrm{gm}$ & 46.82 & 47.00 & 109.30 & 105.59 & 175.30 & 168.37 \\
\hline & L.S.D. 5\% & 2.22 & 2.69 & 3.15 & 2.82 & 3.14 & 3.43 \\
\hline
\end{tabular}

1.2. Effect of irrigation intervals:

Data in Table (1) show that in April 2005 the use of both irrigation intervals of 10 and 15 days gave significant values of plant height (47.60 and $46.41 \mathrm{~cm})$ when compared with the interval of 5 days $(36.67 \mathrm{~cm})$. In April 2006 the greatest value was obtained from the use of 15 days interval (50.78 $\mathrm{cm})$ followed by 10 days interval $(49.11 \mathrm{~cm})$ and there were non significant differences in between while they both were significant when compared with the use of 5 days interval $(36.11 \mathrm{~cm})$.

Similar results were gained in July 2005 as 10 days interval gave the plant height value of $95.33 \mathrm{~cm}$ and the 15 days interval gave $97.93 \mathrm{~cm}$ while the use of 5 days interval gave the lowest value $(84.30 \mathrm{~cm})$. In July 2006, there were non significant differences between using 10 days interval (98.52 $\mathrm{cm})$ and 15 days interval $(96.96 \mathrm{~cm})$ while they both gave significant values when compared with using 5 days interval $(81.56 \mathrm{~cm})$. 
Similar results were obtained in October 2005 as there were non significant differences in plant height values gained by using 10 days (162.04 $\mathrm{cm})$ and 15 days interval $(162.26 \mathrm{~cm})$ but they were both significant when compared with that of 5 days interval $(136.11 \mathrm{~cm})$.

Also, in October 2006 the greatest plant height value was obtained by using 10 days interval $(159.48 \mathrm{~cm})$ followed by the 15 days interval $(158.85 \mathrm{~cm})$ and there were non significant differences in between but they were both significant when compared with the use of 5 days interval (132.22 $\mathrm{cm}$ ). This may be due to the tolerance of Conocarpus to drought or the irrigation intervals of 10 or 15 days were both suitable for the plant requirements whereas the 5 days interval resulted in decreasing of aeration.

\subsection{Effect of fertilization rate:}

Table (1) reveals that in April 2005 using 5 gm NPK per plant gave the greatest value of plant height $(46.89 \mathrm{~cm})$ followed by $10 \mathrm{gm}$ NPK per plant $(46.82 \mathrm{~cm})$ and there were non significant differences in between but, both were significant when compared with the addition of zero $\mathrm{gm} / \mathrm{plant}$ $(36.96 \mathrm{~cm})$. On the other hand, the addition of $5 \mathrm{gm} \mathrm{NPK} /$ plant significantly gave the greatest value of plant height $(51.48 \mathrm{~cm})$ followed by $10 \mathrm{gm}$ NPK/plant $(47.00 \mathrm{~cm})$ and zero gm NPK/plant $(37.52 \mathrm{~cm})$ in April 2006. In July 2005, the application of NPK at the rate of $10 \mathrm{gm} /$ plant significantly gave the highest value of plant height $(109.30 \mathrm{~cm})$ while the addition of $5 \mathrm{gm} /$ plant gave $100.22 \mathrm{~cm}$ and the addition of zero gm/plant gave $68.04 \mathrm{~cm}$. In the same trend, in July 2006 the application of $10 \mathrm{gm} \mathrm{NPK/plant} \mathrm{significantly}$ gave the greatest plant height value $(105.59 \mathrm{~cm})$ while $5 \mathrm{gm} /$ plant gave the value of $102.85 \mathrm{~cm}$ when zero gm/plant gave the value of $68.59 \mathrm{~cm}$. In October 2005 and October 2006, there were significant differences among the three NPK levels. The greatest values were gained by using $10 \mathrm{gm} /$ plant as it gave $175.30 \mathrm{~cm}$ in October 2005 and $168.37 \mathrm{~cm}$ in October 2006 followed by $5 \mathrm{gm} /$ plant as they were $156.63 \mathrm{~cm}$ in October 2005 and 155.85 $\mathrm{cm}$ in October 2006. At last, came the use of zero gm NPK/plant as it gave $128.48 \mathrm{~cm}$ in October 2005 and $126.33 \mathrm{~cm}$ in October 2006. These results may be related to the role of nutrients in plant growth that each plant has its own requirements according to many factors such as plant age, growth season, amount of water, climatic conditions ... etc. These results are in agreement with Devlin (1975) who found that application of NPK fertilization is necessary for the various biochemical processes, which contribute to good plant growth and normal development. Also Brown and Vanden Driessche (2002) stated that fertilization of hybrid poplars Populus spp., one of the most utilized tree types in fast growing plantation, is known to be effective. In addition Jasbir et al. (2006) found that plant height was increased when Lantana camara was amended by NPK fertilizer doses of $50: 50: 25 \mathrm{~kg} / \mathrm{ha}$.

\subsection{Effect of the interaction:}

Data in Table (2) show the effect of interaction during the first season on plant height. It can be observed that clay as a growing medium when irrigation had taken place every 15 days significantly gave the greatest values of plant height for the three dates as they were $54.89,120.78$ and $198.78 \mathrm{~cm}$, respectively when compared with the shorter intervals in most cases. 
Abdalla, M. Y. A. et al.

2

8740 
Interaction between clayey medium and the addition of $5.0 \mathrm{gm} \mathrm{NPK}$ / plant significantly resulted in the greatest values of plant height in the three dates as they were $55.00,126.00$ and $208.22 \mathrm{~cm}$, respectively. From this table also it can be seen that the greatest significant values of plant height in the first season were gained by the use of the interval of 10 days with the addition of $10 \mathrm{gm}$ NPK /plant in July and October as they were 111.00 and $190.22 \mathrm{~cm}$ while, in April the greatest value was obtained due to the use of the same irrigation interval but only when $5 \mathrm{gm} \mathrm{NPK} /$ plant were added as it was 51.11 $\mathrm{cm}$.

The interaction among the three factors clears that the greatest significant values of plant height in April were obtained by the use of clayey medium when received $10 \mathrm{gm} \mathrm{NPK/plant} \mathrm{and} \mathrm{irrigated} \mathrm{every} 10$ days followed by mixture medium when received only $5 \mathrm{gm} \mathrm{NPK/plant} \mathrm{and} \mathrm{the}$ same irrigation interval was used as they were 59.67 and $59.33 \mathrm{~cm}$. On the other hand, the lowest value was $25.00 \mathrm{~cm}$ which obtained from mixture medium when irrigated every 5 days and received no fertilization. In both July and October, the interaction among clayey medium, 15 days irrigation interval and fertilization with $5.0 \mathrm{gm} \mathrm{NPK} /$ plant significantly gave the greatest values of plant height as they were 135.00 and $224.67 \mathrm{~cm}$, respectively while, the lowest values were obtained from sandy medium when irrigated every 5 days and received no fertilization in July and October as they gave 45.00 and $59.67 \mathrm{~cm}$, respectively. However, phosphorous is the main constituent of amino acids, phospholipids, enzymes and ATP. In addition, deficiency of potassium affects respiration process, photosynthesis and movement of stomata which have great effects on plant growth.

Table (3) shows the interaction effects on plant height during 2006. results of interaction between clay as a growing medium and the irrigation interval of 15 days seems to be alike as they significantly gave the greatest values of plant heights in the three dates as they were 56.67, 125.22 and $193.56 \mathrm{~cm}$, respectively.

On the other hand, interaction between mixture medium with the application of $5 \mathrm{gm} \mathrm{NPK/plant} \mathrm{significantly} \mathrm{resulted} \mathrm{in} \mathrm{the} \mathrm{greatest} \mathrm{value} \mathrm{of}$ plant height in April 2006 as it was $59.89 \mathrm{~cm}$ while, in both July and October the greatest significant values of plant heights were obtained from clayey medium with the addition of $5.0 \mathrm{gm} \mathrm{NPK} /$ plant also as they were 128.22 and $199.22 \mathrm{~cm}$, respectively.

It is clear also that the interaction between fertilization with $5 \mathrm{gm}$ NPK/plant with the use of 15 days interval significantly gave the greatest value of plant height in April 2006 as it was $54.78 \mathrm{~cm}$.

Although this value is the greatest in April 2006, there were non significant differences between it and the following one $53.67 \mathrm{~cm}$ that was obtained when irrigation had taken place every 10 days and fertilization was carried out at the rate of $10 \mathrm{gm} \mathrm{NPK/plant.}$

In the same trend, the greatest significant values in the other two dates were obtained from the use of 10 days irrigation interval and application of $10 \mathrm{gm} \mathrm{NPK/plant} \mathrm{also} \mathrm{as} \mathrm{they} \mathrm{were} 114.00$ and $189.11 \mathrm{~cm}$, respectively.

Interaction among the three tested factors shows that the greatest significant value of plant height was $64.33 \mathrm{~cm}$ in April that was obtained from 
either clayey medium irrigated every 10 days and received $10 \mathrm{gm} \mathrm{NPK/plant}$ or mixture medium when irrigated every 15 days and received the same fertilization. In July 2006, clayey medium irrigated every 15 days and fertilized with $10 \mathrm{gm} \mathrm{NPK/plant} \mathrm{significantly} \mathrm{gave} \mathrm{the} \mathrm{greatest} \mathrm{value} \mathrm{of} \mathrm{plant} \mathrm{height} \mathrm{as}$ it was $138.67 \mathrm{~cm}$. The greatest significant value in October was $205.33 \mathrm{~cm}$ that was obtained from clayey medium irrigated every 15 days and received 5 gm NPK/plant.

The lowest values in both April and July were obtained from sandy medium irrigated every 5 days and received no fertilization as they were 20.33 and $39.33 \mathrm{~cm}$, respectively while, in October the lowest one was 65.67 $\mathrm{cm}$ obtained also from sandy medium received no fertilization but irrigated every 10 days.

\section{Effect of soil type, irrigation intervals and fertilization rate on number of branches per plant of Conocarpus erectus during the period from April 2005 to October 2006}

\subsection{Effect of soil type:}

It is observed from Table (4) that in April 2005, the mixture (sand + clay) significantly gave the greatest value of number of branches as it was 16.60. This value is not significant when compared with number of branches gained from clayey soil as it was 15.85 but, they both were significant when compared with the value gained from sandy medium as it was 13.60 .

Similar results were observed in April 2006. In July 2005, the greatest value of number of branches was 35.89 branches in the mixture. There were non significant differences between it and the value obtained from clayey medium as it was 34.89 , while they both were significant when compared with the value of number of branches in sandy medium as it was 26.22. It's clear that in July 2006, the clayey medium significantly gave the highest value of number of branches as it was 38.26 when compared with the mixture medium and sandy medium as they were 36.85 and 26.48. In both October 2005 and October 2006, the mixture medium significantly gave the greatest values of number of branches as they were 62.81 and 64.22 , respectively. These results were significant when compared with other values as number of branches in clayey medium was 55.93 and 56.74 for the two dates while, the lowest values were gained from sandy medium as it was 41.44 in October 2005 and 40.15 in October 2006. This may be related to the ability of clayey soil to hold more water and nutrients besides the role of mixture medium in improving the aeration and nutrients holding characters that roots grow better and this of course reflects on plant growth.

\subsection{Effect of irrigation intervals:}

Table (4) shows also that in both April 2005 and April 2006, the greatest values of number of branches were resulted from the use of 15 days interval as they were 17.60 and 18.78 , respectively. These values were not significant when compared with those gained from the use of 10 days interval in both seasons as they were 17.33 and 18.37 but, these values were significant when compared with values of number of branches when the interval of 5 days was used as they were 11.11 branches in April 2005 and 11.48 branches in April 2006. 
J. Agric. Sci. Mansoura Univ., 33 (12), December, 2008

3

8743 
Abdalla, M. Y. A. et al.

Table (4): Effect of soil type, irrigation intervals and NPK fertilizer rates on number of branches per plant of Conocarpus erectus in two seasons

\begin{tabular}{|c|c|c|c|c|c|c|c|}
\hline \multirow{6}{*}{$\begin{array}{l}\text { Soil type } \\
\text { (A) }\end{array}$} & \multirow{2}{*}{ Treatments } & \multicolumn{2}{|c|}{ April } & \multicolumn{2}{|c|}{ July } & \multicolumn{2}{|c|}{ October } \\
\hline & & 2005 & 2006 & 2005 & 2006 & 2005 & 2006 \\
\hline & Sand & 13.60 & 14.33 & 26.22 & 26.48 & 41.44 & 40.15 \\
\hline & Clay & 15.85 & 17.00 & 34.89 & 38.26 & 55.93 & 56.74 \\
\hline & Sand + clay & 16.60 & 17.30 & 35.89 & 36.85 & 62.81 & 64.22 \\
\hline & L.S.D 5\% & 0.98 & 0.99 & 1.49 & 0.95 & 1.64 & 1.34 \\
\hline \multirow{4}{*}{$\begin{array}{l}\text { Irrigation } \\
\text { intervals } \\
\text { (B) }\end{array}$} & 5 days & 11.11 & 11.48 & 27.70 & 27.56 & 46.52 & 45.41 \\
\hline & 10 days & 17.33 & 18.37 & 33.18 & 37.15 & 58.70 & 59.74 \\
\hline & 15 days & 17.60 & 18.78 & 36.11 & 36.89 & 54.96 & 55.96 \\
\hline & L.S.D 5\% & 0.97 & 0.99 & 1.47 & 1.13 & 1.49 & 1.18 \\
\hline \multirow{4}{*}{$\begin{array}{l}\text { Fertilization } \\
\text { rate } \\
\text { (C) }\end{array}$} & $0.0 \mathrm{gm}$ & 13.48 & 14.44 & 26.15 & 27.56 & 45.52 & 44.56 \\
\hline & $5.0 \mathrm{gm}$ & 16.41 & 17.78 & 34.48 & 35.89 & 55.96 & 57.22 \\
\hline & $10.0 \mathrm{gm}$ & 16.15 & 16.40 & 36.37 & 38.15 & 58.70 & 59.33 \\
\hline & L.S.D 5\% & 1.27 & 1.31 & 1.94 & 1.50 & 1.96 & 1.56 \\
\hline
\end{tabular}

In July 2005, 15 days interval significantly gave the greatest value of number of branches as it was 36.11 branches. The lowest value was 27.70 branches when 5 days interval was used while, the 10 days interval gave the value of 33.18 branches. In July 2006, 10 days interval gave the greatest value of number of branches as it was 37.15 branches. This value is not significant when compared with the value gained from the use of 15 days interval as it was 36.89 branches. Both values were significant when compared with that achieved from the use of 5 days interval as it was 27.56 branches.

In October 2005, the use of 10 days interval significantly gave the greatest value of number of branches followed by 15 days interval and at last came the 5 days interval as they were $58.70,54.96$ and 46.52 , respectively. Similar results were gained in October 2006 that the greatest value of number of branches was obtained from the use of 10 days interval as it was 59.74 branches. This value is significant when compared with the following one obtained from the use of 15 days interval as it was 55.96, or the lowest one of 45.41 which was gained from the use of the 5 days interval. This could be due to the low need of water of this plant since when it was irrigated every 10 or 15 days it grew better than if irrigated every 5 days.

\subsection{Effect of fertilization rate:}

Table (4) also shows that in April 2005, there were no significant differences between the effect of 5 or $10 \mathrm{gm} /$ plant NPK application on number of branches as they were 16.41 and 16.15 , respectively while, they both were significant when compared with the application of zero gm/plant as it was 13.48 branches. In April 2006, the use of $5 \mathrm{gm} \mathrm{NPK/plant} \mathrm{significantly}$ gave the greatest value of number of branches as it was 17.78. The lowest value was 14.44 branches without using NPK fertilizer while, the use of 10 gm NPK/plant gave the value of 16.40 .

In July 2005, the greatest value of number of branches was gained from the addition of $10 \mathrm{gm} \mathrm{NPK/plant} \mathrm{as} \mathrm{it} \mathrm{was} \mathrm{36.37.} \mathrm{There} \mathrm{were} \mathrm{non}$ significant differences between it and the following value gained from the application of $5 \mathrm{gm} \mathrm{NPK} /$ plant as it was 34.48 while, they both were significant when compared with the lowest value gained from the application 
of zero gm NPK/plant as it was 26.15. In July 2006, the application of $10 \mathrm{gm}$ $\mathrm{NPK} /$ plant significantly gave the greatest value of number of branches as it was 38.15 while, the lowest value was 27.56 branches gained from the application of zero gm NPK/plant and the application of $5 \mathrm{gm} \mathrm{NPK/plant} \mathrm{gave}$ the value of 35.89 branches.

Results measured in October 2005 showed that the application of 10 gm NPK/plant significantly gave the greatest value of number of branches as it was 58.70). The lowest value was obtained when no NPK fertilizers were applied as it was 45.52, while the application of $5 \mathrm{gm} \mathrm{NPK/plant} \mathrm{gave} \mathrm{the}$ value of 55.96 branches. In the same trend, in October 2006 the greatest value of number of branches was obtained from the application of $10 \mathrm{gm}$ $\mathrm{NPK} /$ plant as it was 59.33 branches. This value is significant when compared with either that of $5 \mathrm{gm} \mathrm{NPK/plant} \mathrm{(57.22)} \mathrm{or} \mathrm{the} \mathrm{lowest} \mathrm{one} \mathrm{(44.56)} \mathrm{branches}$ which was gained from the addition of no fertilizers. This may be due to the moderate need of every plant to nutrients for best growth and each plant has its own requirements due to many conditions but fertilization must occurs. These results are in agree with Brown and Vanden Driessche (2002), and Atta-Alla (2003) on cineraria plants who found that number of branches per plant was significantly affected by fertilizer rate.

\subsection{Effect of the interaction:}

Table (5) refers to the interaction effects on number of branches during 2005. It is clear that the greatest significant values of number of branches in both April and October were obtained due to the interaction between mixture medium and the 10 days interval as they were 19.44 and 68.22 , respectively while, in July the greatest value was 41.56 branches which was gained from the same media but irrigated every 15 days.

Interaction between mixture medium and $5 \mathrm{gm} \mathrm{NPK/plant}$ significantly gave the greatest values of number of branches in the three dates as they were $19.33,39.56$ and 71.67 respectively.

On the other hand, interaction between 15 days interval and $5 \mathrm{gm}$ NPK/plant significantly gave the greatest value of number of branches in April 2005 as it was 18.33 branches while, in July the greatest significant one was 38.11 branches which was gained from the use of 15 days interval also but with $10 \mathrm{gm} \mathrm{NPK/plant.}$

In October, the greatest significant one was 64.22 branches that obtained due to the interaction between 10 days interval and $10 \mathrm{gm}$ NPK/plant.

Interaction among the three factors in April 2005 clears that the greatest significant value was 21.00 branches which was obtained from mixture medium when irrigated every 15 days and received $5 \mathrm{gm} \mathrm{NPK/plant.}$ On the other hand, the greatest significant one in July was obtained from mixture medium irrigated every 15 days but received $10 \mathrm{gm} \mathrm{NPK} /$ plant as it was 45.33 while, in October mixture medium when irrigated every 10 days and fertilized with $5 \mathrm{gm} \mathrm{NPK/plant} \mathrm{gave} \mathrm{significantly} \mathrm{the} \mathrm{greatest} \mathrm{value} \mathrm{of}$ number of branches as it was 78.33 .

The least values in both July and October were gained from sandy medium when irrigated every 15 days and received no fertilization as they were 15.67 and 27.67, respectively while, the least one in April was 6.00 
Abdalla, M. Y. A. et al.

branches which was obtained from clayey medium irrigated every 5 days without fertilization.

Data in Table (6) show the interaction effects during 2006. It can be noticed that in both July and October 2006, the interaction between mixture medium and 15 days irrigation interval resulted in the greatest significant values of number of branches as they were 42.78 and 70.89 , respectively while, the interaction between the same media and 15 days interval in April 2006 gave significantly the greatest value as it was 20.33 .

Interaction between clayey medium and $5 \mathrm{gm} \mathrm{NPK} /$ plant gave significantly the greatest value of number of branches in July 2006 followed by mixture medium fertilized with the same rate without significant differences between each other as they were 42.89 and 42.78 , respectively.

In the same trend, in both April and October, the interaction between mixture medium and application of $5 \mathrm{gm} \mathrm{NPK/plant} \mathrm{led} \mathrm{to} \mathrm{the} \mathrm{greatest} \mathrm{significant}$ values of number of branches as they were 20.78 and 79.67, respectively.

The interaction between irrigation intervals and NPK additions reveals that in April, the greatest significant value was 20.00 branches which was obtained from the use of 15 days interval with $5 \mathrm{gm} \mathrm{NPK/plant} \mathrm{addition}$ whereas, the greatest significant value in July was 40.00 which was gained from the use of 10 days irrigation interval and $10 \mathrm{gm} \mathrm{NPK} /$ plant application but, in October, the greatest significant value was 66.00 branches which was obtained due to the interaction between 10 days irrigation interval and the use of $5 \mathrm{gm} \mathrm{NPK/plant} \mathrm{application.}$

The triple interaction shows that in both July and October 2006 the greatest significant values of number of branches were resulted from mixture medium when irrigated every 15 days and received $5 \mathrm{gm} \mathrm{NPK} /$ plant as they were 50.33 and 89.67, respectively while, in April, clayey medium irrigated every 10 days and fertilized with $5 \mathrm{gm} \mathrm{NPK/plant} \mathrm{either} \mathrm{gave} \mathrm{significantly} \mathrm{the}$ greatest value as it was 23.67 branches as compared with other treatments.

The least values in the three dates were obtained from sandy medium irrigated every 5 days and received no fertilizer fertilized as they were $6.00,13.00$ and 21.33 branches per plant, respectively.

3. Effect of soil type, irrigation intervals and fertilization rate on stem diameter of Conocarpus erectus from April 2005 to October 2006

Data of stem diameter of Conocarpus were statistically analyzed and represented in Tables from (7) to (9).

\subsection{Effect of soil type:}

Data in Table (7) reveal that sand + clay medium gave the greatest stem diameter of Conocarpus stem as it was $4.34 \mathrm{~mm}$ followed by clayey medium as it was $4.32 \mathrm{~mm}$. The two values were significant when compared with the sandy medium $(3.54 \mathrm{~mm})$ but there were non significant differences between them in April 2005. Similar results were gained in April 2006 as both clayey media and sand + clay mixture gave significantly the highest values of stem diameter as they were 4.67 and $4.59 \mathrm{~mm}$ with non significant differences between each other while, they both were significant when compared with the value of stem diameter obtained from sandy medium as it was $3.70 \mathrm{~mm}$. 
J. Agric. Sci. Mansoura Univ., 33 (12), December, 2008

5 
Abdalla, M. Y. A. et al.

6

8748 
Table (7): Effect of soil type, irrigation intervals and NPK fertilizers rate on stem diameter $(\mathrm{mm})$ of Conocarpus erectus in two seasons

\begin{tabular}{|c|c|c|c|c|c|c|c|}
\hline \multirow{4}{*}{$\begin{array}{c}\text { Soil type } \\
\text { (A) }\end{array}$} & Treatments & \multicolumn{2}{|c|}{ April } & \multicolumn{3}{c|}{ July } & \multicolumn{2}{c|}{ October } \\
\cline { 2 - 7 } & Sand & $\mathbf{2 0 0 5}$ & $\mathbf{2 0 0 6}$ & $\mathbf{2 0 0 5}$ & $\mathbf{2 0 0 6}$ & $\mathbf{2 0 0 5}$ & $\mathbf{2 0 0 6}$ \\
\cline { 2 - 8 } & Clay & 4.34 & 3.70 & 7.62 & 8.00 & 14.00 & 14.00 \\
\cline { 2 - 8 } & $\begin{array}{c}\text { Sand + } \\
\text { clay }\end{array}$ & 4.34 & 4.67 & 11.76 & 12.60 & 25.32 & 27.12 \\
\cline { 2 - 8 } & L.S.D 5\% & 0.45 & 0.75 & 0.81 & 0.83 & 1.33 & 0.95 \\
\hline $\begin{array}{c}\text { Irrigation } \\
\text { intervals } \\
\text { (B) }\end{array}$ & $\mathbf{5 ~ d a y s ~}$ & 3.06 & 3.14 & 7.30 & 7.79 & 17.18 & 17.74 \\
\cline { 2 - 8 } & $\mathbf{1 0 ~ d a y s}$ & 4.47 & 4.71 & 10.15 & 10.66 & 22.47 & 23.79 \\
\cline { 2 - 8 } & $\mathbf{1 5}$ days & 4.67 & 5.11 & 11.84 & 12.65 & 23.09 & 23.99 \\
\cline { 2 - 8 } & L.S.D 5\% & 0.49 & 0.53 & 0.96 & 0.90 & 1.16 & 1.15 \\
\hline $\begin{array}{c}\text { Fertilization } \\
\text { rate } \\
\text { (C) }\end{array}$ & $\mathbf{0 . 0 ~ g m ~}$ & 3.35 & 3.55 & 6.84 & 7.52 & 17.53 & 18.60 \\
\cline { 2 - 8 } & $\mathbf{5 . 0}$ gm & 4.50 & 4.61 & 10.75 & 11.28 & 21.31 & 22.56 \\
\cline { 2 - 8 } & $\mathbf{1 0 . 0 ~ g m ~}$ & 4.35 & 4.81 & 11.70 & 12.29 & 23.90 & 24.36 \\
\cline { 2 - 8 } & L.S.D 5\% & 0.65 & 0.70 & 1.26 & 1.18 & 1.52 & 1.51 \\
\hline
\end{tabular}

In July 2005, clayey medium significantly resulted in the largest button wood stem diameter of $11.76 \mathrm{~mm}$ when compared with sand + clay mixture as it was $9.91 \mathrm{~mm}$ or the lowest one obtained from sandy as it was $7.62 \mathrm{~mm}$. Also, in July 2006 clayey medium gave significantly the highest stem diameter as it was $12.60 \mathrm{~mm}$ when compared with sand + clay mixture that was $10.49 \mathrm{~mm}$ and also when compared with sandy medium as it was $8.00 \mathrm{~mm}$ with significant differences among the three media. The greatest values of stem diameter in both October 2005 and October 2006 were due to the use of clayey media as they were 25.32 and $27.12 \mathrm{~mm}$, respectively. In the two dates, values of stem diameter gained from clayey medium were significant when compared with those gained from the mixture as they were $23.42 \mathrm{~mm}$ in October 2005 and $24.40 \mathrm{~mm}$ in October 2006. The lowest values in both seasons were obtained from sandy medium as it was 14.00 $\mathrm{mm}$ in both October 2005 and 2006.

\subsection{Effect of irrigation intervals:}

Table (7) shows that in April 2005 the use of 15 days interval gave the greatest value of stem diameter as it was $4.67 \mathrm{~mm}$ followed by 10 days interval $(4.47 \mathrm{~mm})$ with non significant differences between them but, they both were significant when compared with the use of 5 days interval as it was $3.06 \mathrm{~mm}$. In the same trend, in April 2006 both 15 and 10 days interval gave significantly higher values of stem diameter as they were 5.11 and $4.71 \mathrm{~mm}$, respectively when compared with this of 5 days interval as it was $3.14 \mathrm{~mm}$. Similar results were obtained in July 2005 as 15 days interval gave significantly the highest value of stem diameter as it was $11.84 \mathrm{~mm}$ when compared with other intervals while, the lowest value was resulted in the use of 5 days interval as it was only $7.30 \mathrm{~mm}$.

In July 2006, 15 days interval gave significantly the highest value of stem diameter as it was $12.65 \mathrm{~mm}$ when compared with the other intervals as they were $7.79 \mathrm{~mm}$ for 5 days interval and $10.66 \mathrm{~mm}$ for the 10 days interval.

In October 2005, 15 days interval gave significantly the biggest value of stem diameter as it was $23.09 \mathrm{~mm}$. This value is significant when compared with other values as the use of 10 days interval gave the value of 
Abdalla, M. Y. A. et al.

$22.47 \mathrm{~mm}$ while the lowest value was resulted from the use of 5 days interval as it was only $17.18 \mathrm{~mm}$. Non significant differences were observed between the use of 15 or 10 days interval in October 2006 as they were 23.79 and $23.99 \mathrm{~mm}$ but, they both were significant when compared with that of 5 days interval as it was $17.74 \mathrm{~mm}$.

\subsection{Effect of fertilization rate:}

It is clear from Table (7) that in both April 2005 and April 2006 there were non significant differences between either the addition of 5 or $10 \mathrm{gm}$ $\mathrm{NPK} /$ plant as they significantly were 4.50 and $4.35 \mathrm{~mm}$ in April 2005 and 4.61 and $4.81 \mathrm{~mm}$ in April 2006, respectively. The lowest stem diameter values were obtained when no fertilizers were added as they were $3.35 \mathrm{~mm}$ in April 2005 and $3.55 \mathrm{~mm}$ in April 2006. In July 2005, similar results were obtained as both the addition of 5 and $10 \mathrm{gm} \mathrm{NPK/} \mathrm{plant} \mathrm{had} \mathrm{non} \mathrm{significant}$ differences between them as they were 10.75 and $11.70 \mathrm{~mm}$ but they were both significant when compared with the zero gm/plant NPK application as it was $6.84 \mathrm{~mm}$. Similar results were obtained in July 2006 that the greatest value of stem diameter was gained from the addition of $10 \mathrm{gm} \mathrm{NPK} /$ plant followed by the addition of $5 \mathrm{gm} /$ plant as they were 12.29 and $11.28 \mathrm{~mm}$, respectively with non significant differences between each other but, they both were significant when compared with the zero NPK addition as it was $7.52 \mathrm{~mm}$ in diameter.

There is a difference in October 2005 and October 2006, its clear that the use of $10 \mathrm{gm} /$ plant NPK addition gave significantly the greatest value of stem diameter as it was $23.90 \mathrm{~mm}$ in October 2005 and $24.36 \mathrm{~mm}$ in October 2006. On the other hand, the lowest values of stem diameter were obtained with no NPK additions as it was $17.53 \mathrm{~mm}$ in October 2005 and $18.60 \mathrm{~mm}$ in October 2006.

\subsection{Effect of the interaction:}

Data in Table (8) show the effect of interaction of the three tested factors on stem diameter in 2005. The greatest significant value of stem diameter was resulted from the interaction between mixture medium and 15 days interval in April 2005 as it was $5.11 \mathrm{~mm}$ while, in both July and October, the greatest values were resulted from the interaction between clayey medium with the interval of 15 days also as they were 16.06 and $28.98 \mathrm{~mm}$, respectively.

The interaction between clayey medium and the addition of $5 \mathrm{gm}$ NPK/plant gave significantly the greatest values of stem diameter in both July and October as they were 14.58 and $29.00 \mathrm{~mm}$, respectively while, the greatest significant value in April was $5.03 \mathrm{~mm}$ which was obtained from mixture medium when received $5 \mathrm{gm} \mathrm{NPK/plant.} \mathrm{When} \mathrm{soil} \mathrm{type} \mathrm{is} \mathrm{neglected,}$ the greatest significant value of stem diameter was obtained in April from the use of the irrigation interval of 15 days with $5 \mathrm{gm} \mathrm{NPK/plant} \mathrm{whereas,} \mathrm{in} \mathrm{July,}$ it was obtained from the same irrigation interval but received $10 \mathrm{gm}$ $\mathrm{NPK} /$ plant while, in October, the greatest significant value was obtained from the use of 10 days interval with $10 \mathrm{gm} \mathrm{NPK/plant} \mathrm{as} \mathrm{they} \mathrm{were} \mathrm{5.28,} 14.01$ and $25.80 \mathrm{~mm}$, respectively. 
J. Agric. Sci. Mansoura Univ., 33 (12), December, 2008

8

8751 
Interaction among the three tested factors in the first season clears that generally, in the three measuring dates, the interaction among clayey medium, 5 days interval and $5 \mathrm{gm} \mathrm{NPK} /$ plant gave significantly the greatest values of stem diameter as they were $6.10,19.23$ and $35.37 \mathrm{~mm}$, respectively. On the other hand, the least values were resulted from clayey medium irrigated every 5 days without fertilization in April as it was $2.40 \mathrm{~mm}$, sandy medium irrigated with the same interval without fertilization also in April as it was $2.47 \mathrm{~mm}$.

Results of interaction in the second season were shown in Table (9). It can be noticed that the interaction between clayey medium and 15 days interval gave significantly the greatest value of stem diameter in the three dates as they were $5.63,17.23$ and $30.89 \mathrm{~mm}$, respectively. In the same trend, clayey medium when received $5 \mathrm{gm} \mathrm{NPK/plant} \mathrm{in} \mathrm{the} \mathrm{three} \mathrm{dates} \mathrm{gave}$ significantly the greatest values of stem diameter as they were 5.16, 15.56 and $32.02 \mathrm{~mm}$, respectively. In April 2006, the interaction between 15 days interval and $5 \mathrm{gm} \mathrm{NPK} /$ plant gave significantly the greatest value of stem diameter as it was $6.26 \mathrm{~mm}$.

Interaction between the same irrigation interval and $10 \mathrm{gm} \mathrm{NPK/plant}$ gave significantly the greatest value of stem diameter in July as it was 14.14 $\mathrm{mm}$ while, the use of 10 days interval with $10 \mathrm{gm} \mathrm{NPK} /$ plant gave the greatest significant value in October as it was $27.00 \mathrm{~mm}$. The triple interaction reveals that in both July and October, clayey medium irrigated every 15 days and received $5 \mathrm{gm}$ NPK/plant gave significantly the greatest values of stem diameter as they were 21.10 and $40.63 \mathrm{~mm}$ while, in April, the greatest significant value was resulted from the same irrigation interval with the same NPK addition but in mixture medium as it was $6.47 \mathrm{~mm}$. The lowest values were obtained from sandy medium irrigated every 5 days whether received no fertilizers in April, July and October as they were 2.27, 3.40 and $6.07 \mathrm{~mm}$, respectively.

4. Effect of soil type, irrigation intervals and NPK applications on dry matter (\%) of Conocarpus erectus during the two seasons 2005 and 2006

Data of dry matter (\%) of Conocarpus were statistically analyzed and represented in Tables (10) and (11).

4.1. Effect of soil type:

Table (10) reveals that the greatest value of dry matter was $29.16 \%$ gained from clayey soil followed by the mixture $(28.70 \%)$ with no significant differences between them but, they both were significant when compared with the lowest value gained from sandy medium as it was $25.90 \%$ in the first season. Similar results are shown in Table (11) as in the second season the greatest value of dry matter \% was obtained from clayey medium followed by that from mixture medium as they were 29.44 and $28.34 \%$, respectively without significant difference between each other while, they both were significant when compared with the value obtained from sandy medium $(26.03 \%)$.

\subsection{Effect of irrigation intervals:}

In the first season there were no significant differences among values of dry matter \% obtained by the use of 5,10 and 15 days interval 
J. Agric. Sci. Mansoura Univ., 33 (12), December, 2008

9

8753 
The greatest significant values of dry matter \% in both seasons were obtained from mixture medium irrigated every 5 days and fertilized with 10 gm NPK/plant as they were 33.60 and $34.64 \%$, respectively. On the other hand, the lowest values of dry matter \% in both seasons were obtained from sandy medium when irrigated every 10 days and received no NPK fertilizers as they were 24.16 and $23.60 \%$, respectively.

Table (11): Effect of soil type, irrigation intervals and NPK fertilizers rate and their interaction on dry matter \% of Conocarpus erectus in October 2006

\begin{tabular}{|c|c|c|c|c|c|c|}
\hline \multirow{2}{*}{$\begin{array}{l}\text { Soil type } \\
\text { (A) }\end{array}$} & \multirow{2}{*}{$\begin{array}{l}\text { Irrigation } \\
\text { intervals } \\
\text { (B) }\end{array}$} & \multicolumn{3}{|c|}{$\begin{array}{l}\text { NPK (gm / plant) } \\
\text { (C) }\end{array}$} & \multirow{2}{*}{$\begin{array}{l}\text { Mean of } \\
(\mathrm{AxB})\end{array}$} & \multirow{2}{*}{$\begin{array}{l}\text { Mean of } \\
\text { (A) }\end{array}$} \\
\hline & & 0.0 & 5.0 & 10.0 & & \\
\hline \multirow{3}{*}{ Sandy } & 5 & 25.60 & 27.20 & 25.80 & 26.20 & \multirow{3}{*}{26.03} \\
\hline & 10 & 23.60 & 25.80 & 27.99 & 25.80 & \\
\hline & 15 & 26.30 & 26.00 & 26.00 & 26.10 & \\
\hline \multicolumn{2}{|c|}{ Mean of $(A \times C)$} & 25.17 & 26.33 & 26.60 & & \multirow{4}{*}{29.44} \\
\hline \multirow{3}{*}{ Clayey } & 5 & 25.70 & 29.30 & 34.40 & 29.79 & \\
\hline & 10 & 27.00 & 28.50 & 33.60 & 29.70 & \\
\hline & 15 & 29.60 & 27.66 & 29.22 & 28.83 & \\
\hline \multicolumn{2}{|c|}{ Mean of $(A \times C)$} & 27.43 & 28.49 & 32.41 & & \multirow{4}{*}{28.34} \\
\hline \multirow{3}{*}{$\begin{array}{c}\text { Sand } \\
+ \\
\text { clay }\end{array}$} & 5 & 26.41 & 29.30 & 34.64 & 30.12 & \\
\hline & 10 & 24.44 & 29.40 & 28.00 & 27.28 & \\
\hline & 15 & 24.99 & 26.65 & 31.25 & 27.63 & \\
\hline \multicolumn{2}{|c|}{ Mean of $(A \times C)$} & 25.28 & 28.45 & 31.30 & Mean of & \multirow{5}{*}{$\begin{array}{lr}\text { L.S.D } & 5 \% \\
\text { A } & 1.73 \\
\text { B } & 0.97 \\
\text { C } & 1.28 \\
\text { AB } & 1.00 \\
\text { AC } & 1.31 \\
\text { BC } & 1.31 \\
\text { ABC } & 1.60 \\
\end{array}$} \\
\hline \multirow{3}{*}{$\begin{array}{l}\text { Mean of } \\
(B \times C)\end{array}$} & 5 & 25.90 & 28.60 & 31.61 & $\begin{array}{c}\text { (B) } \\
28.71\end{array}$ & \\
\hline & 10 & 25.01 & 27.90 & 29.87 & 27.59 & \\
\hline & 15 & 26.97 & 26.77 & 28.82 & 27.52 & \\
\hline \multicolumn{2}{|c|}{ Mean of (C) } & 25.96 & 27.76 & 30.10 & & \\
\hline
\end{tabular}

5- Effect of soil type, irrigation intervals and NPK applications on Chlorophyll a, b and total chlorophyll content of Conocarpus erectus in $\mathrm{mg}$ chl./gm fresh weigh during 2005 and 2006.

Tables from (12) to (14) represent the statistically analyzed data of chlorophyll contents.

\subsection{Effect of soil types:}

5.1.1. Effect of soil type on chlorophyll a content:

Data in Table (12) reveal that there were non significant differences among chlorophyll a content values obtained from sandy, clayey and the mixture medium as they were $0.24,0.37$ and $0.35 \mathrm{mg} \mathrm{chl} . / \mathrm{gm}$ fresh weight in 2005 , respectively while they were $0.24,0.39$ and $0.35 \mathrm{mg}$ chl. $/ \mathrm{mg}$ fresh weight in 2006 in the same order.

\subsubsection{Effect of soil type on chlorophyll b content:}

It can be observed from Table (13) that different soil types had also non significant effects on chlorophyll b content values in both 2005 and 2006 as they were $0.16,0.27$ and $0.28 \mathrm{mg} \mathrm{chl}$. /gm fresh weight for sandy, clayey and mixture media, respectively in 2005 while, they were $0.17,0.32$ and 0.25 $\mathrm{mg} \mathrm{chl.} \mathrm{/gm} \mathrm{fresh} \mathrm{weight} \mathrm{in} 2006$ in the same order. 
Abdalla, M. Y. A. et al.

12

8756 
J. Agric. Sci. Mansoura Univ., 33 (12), December, 2008

13 


\subsubsection{Effect of soil type on total chlorophyll content:}

Table (14) shows that although the greatest values of total chlorophyll content were obtained from clayey medium (0.62) and (0.72) in 2005 and 2006, there were non significant differences between them and those obtained from either mixture $(0.60)$ and $(0.59)$ or sandy medium $(0.40)$ and $(0.41)$ in 2005 and 2006, respectively. Although the soil type affects plant growth, the chlorophyll $\mathrm{a}, \mathrm{b}$ and total content were not affected by soil type. This may be due to the ability of Conocarpus to grow in poor soils. However, the least values of total chlorophyll were of plants in sandy medium.

\subsection{Effect of irrigation intervals:}

5.2.1. Effect of irrigation intervals on chlorophyll a content:

Table (12) reveals that values of chlorophyll a content were 0.35 , 0.31 and $0.29 \mathrm{mg}$ chl. /gm fresh weight for 5,10 and 15 days interval with non significant differences among them in 2005. Similar results are shown in 2006 as there were non significant differences among chlorophyll a content values when 5,10 and 15 days interval were used as they were $0.35,0.33$ and $0.30 \mathrm{mg} \mathrm{chl} . / \mathrm{gm}$ fresh weight, respectively.

\subsubsection{Effect of irrigation intervals on chlorophyll b content:}

Table (13) clears that whether in 2005 or 2006 the different irrigation intervals had a non significant effect on chlorophyll $b$ content values as they were $0.27,0.22$ and $0.23 \mathrm{mg} \mathrm{chl} / \mathrm{gm}$ fresh $\mathrm{w}$. in 2005 while, they were 0.30 , 0.23 and $0.21 \mathrm{mg} \mathrm{chl} / \mathrm{gm}$ fresh $\mathrm{w}$. in 2006 for 5,10 and 15 days intervals, respectively.

\subsubsection{Effect of irrigation intervals on total chlorophyll content:}

In the same trend, the different irrigation intervals had non significant effects on total chlorophyll content values in both seasons as shown in Table (14). In the first season the values were $0.61,0.51$ and $0.50 \mathrm{mg} \mathrm{chl} . / \mathrm{gm}$ fresh w. for 5,10 and 15 days interval while they were $0.64,0.57$ and $0.51 \mathrm{mg} \mathrm{chl}$. / $\mathrm{gm}$ fresh $\mathrm{w}$. in the second season in the same order. It may be also due to the ability of this plant to grow and survive under drought conditions.

\subsection{Effect of NPK applications:}

\subsubsection{Effect of NPK application on chlorophyll a content:}

Table (12) shows that in the first season the different NPK applications had non significant effects on chlorophyll a content values as they were $0.22,0.37$ and $0.37 \mathrm{mg} \mathrm{chl}$. $/ \mathrm{gm}$ fresh weight when fertilized with zero, 5 and $10 \mathrm{gm} \mathrm{NPK/plant,} \mathrm{respectively.} \mathrm{Similar} \mathrm{results} \mathrm{could} \mathrm{be} \mathrm{observed}$ in the second season as the values were $0.22,0.38$ and $0.38 \mathrm{mg} \mathrm{chl} . / \mathrm{gm}$ fresh weight when received zero, 5 and $10 \mathrm{gm} \mathrm{NPK/plant} \mathrm{without} \mathrm{significant}$ differences among themselves.

\subsubsection{Effect of NPK application on chlorophyll b content:}

In the same trend, the different NPK applications had non significant effects on chlorophyll $b$ content values as shown in Table (13). Values were $0.16,0.27$ and $0.28 \mathrm{mg} \mathrm{chl}$. $/ \mathrm{gm}$ fresh weight when received zero, 5 and 10 $\mathrm{gm} \mathrm{NPK/plant} \mathrm{in} \mathrm{the} \mathrm{first} \mathrm{season,} \mathrm{respectively} \mathrm{while} \mathrm{they} \mathrm{were} 0.13,0.31$ and $0.25 \mathrm{mg} \mathrm{chl} / \mathrm{gm}$ fresh weight in the same order in the second season.

\subsubsection{Effect of NPK application on total chlorophyll content:}

Table (14) clears that there were non significant differences among total chlorophyll content values obtained from adding zero, 5 and $10 \mathrm{gm}$ 
$\mathrm{NPK} /$ plant as they were $0.36,0.63$ and $0.64 \mathrm{mg} \mathrm{chl}$. /gm fresh weight in the first season. Similar results can be observed for the second season as the values were $0.36,0.70$ and $0.66 \mathrm{mg}$ chl./ gm fresh weight with non significant differences among themselves. It can be also related to the previous refer to the ability of this plant to grow and develop under unsuitable conditions.

\subsection{Effect of the interactions:}

\subsubsection{Effect of interactions on chlorophyll a content:}

Table (12) reveals that in both seasons clayey medium when irrigated every 5 days gave significantly the greatest values of chlorophyll a content as they were 0.41 and $0.43 \mathrm{mg} \mathrm{chl} . / \mathrm{gm}$ fresh weight, respectively.

The interaction between clayey medium and $10 \mathrm{gm} \mathrm{NPK} /$ plant gave significantly the greatest value of chlorophyll a content in both 2005 and 2006 as they were 0.43 and $0.49 \mathrm{mg} \mathrm{chl} . / \mathrm{gm}$ fresh weight, respectively.

The interaction between irrigation intervals and NPK additions clears that the greatest significant values of chlorophyll a content in both seasons were resulted from the use of 5 days interval and $10 \mathrm{gm} \mathrm{NPK} /$ plant as they were 0.45 and $0.46 \mathrm{mg} \mathrm{chl}$. /gm fresh weight, respectively.

The triple interaction among the three tested factors shows that in both seasons the clayey medium when irrigated every 5 days and received $10 \mathrm{gm} \mathrm{NPK/plant} \mathrm{gave} \mathrm{significantly} \mathrm{the} \mathrm{greatest} \mathrm{values} \mathrm{of} \mathrm{chlorophyll} \mathrm{a}$ content as they were 0.54 and $0.60 \mathrm{mg} \mathrm{chl} . \mathrm{gm}$ fresh weight, respectively.

On the other hand, the lowest values of chlorophyll a content were gained when sandy medium was irrigated every 5 days and received no NPK fertilizers at all as they were 0.14 and $0.10 \mathrm{mg}$ chl. $/ \mathrm{gm}$ fresh weight in 2005 and 2006, respectively.

\subsubsection{Effect of interactions on chlorophyll b content:}

Data in Table (13) show that in the first season the interaction between mixture medium and 5 days interval gave significantly the greatest value of chlorophyll b content as it was $0.34 \mathrm{mg} \mathrm{chl}$. $/ \mathrm{gm}$ fresh weight whereas in the second season the clayey medium irrigated with the same interval gave significantly the greatest value as it was $0.38 \mathrm{mg} \mathrm{chl} . / \mathrm{gm}$ fresh weight.

In both seasons, the interaction between clayey medium and $10 \mathrm{gm}$ NPK/plant gave significantly the greatest value of chlorophyll b content as they were 0.35 and $0.40 \mathrm{mg}$ chl. $/ \mathrm{gm}$ fresh weight, respectively.

Interaction between 5 days interval and $10 \mathrm{gm} \mathrm{NPK} /$ plant gave significantly the greatest values of chlorophyll $b$ content in both seasons as they were 0.38 and $0.39 \mathrm{mg} \mathrm{chl} . / \mathrm{gm}$ fresh weight, respectively .

Interaction among the three factors shows that clayey medium when irrigated every 5 days and fertilized with $10 \mathrm{gm} \mathrm{NPK/plant} \mathrm{gave} \mathrm{significantly}$ the greatest values of chlorophyll b content in both 2005 and 2006 as they were 0.48 and $0.52 \mathrm{mg} \mathrm{chl}$. /gm fresh weight, respectively. The least value was obtained from sandy medium when irrigated every 5 days without fertilization as it was only $0.06 \mathrm{mg} \mathrm{chl}$. /gm fresh weight for each season.

\subsubsection{Effect of the interaction on total chlorophyll content:}

Table (14) shows that in 2005, the interaction between both clayey medium and 5 days interval or mixture medium with the same interval gave significantly the greatest value of total chlorophyll content as they both gave 
Abdalla, M. Y. A. et al.

14

8760 
the same value of $0.70 \mathrm{mg}$ chl. /gm fresh weight while, in 2006, the clayey medium only irrigated every 5 days gave significantly the greatest value of total chlorophyll as it was $0.79 \mathrm{mg} \mathrm{chl} . / \mathrm{gm}$ fresh weight.

In both seasons, clayey medium fertilized with $10 \mathrm{gm} \mathrm{NPK/plant} \mathrm{gave}$ significantly the greatest values of total chlorophyll content as they were 0.74 and $0.89 \mathrm{mg} \mathrm{chl}$. /gm fresh weight, respectively.

Interaction between irrigation intervals and NPK additions clears that the use of 5 days interval with the application of $10 \mathrm{gm} \mathrm{NPK/plant} \mathrm{in} \mathrm{both}$ seasons gave significantly the greatest values of total chlorophyll content as they were 0.81 and $0.82 \mathrm{mg} \mathrm{chl}$. $/ \mathrm{gm}$ fresh weight, respectively. The greatest significant total chlorophyll values in both seasons resulted from clayey medium, irrigated every 5 days and received $10 \mathrm{gm} \mathrm{NPK/plant} \mathrm{as} \mathrm{they} \mathrm{were}$ 1.02 and $1.07 \mathrm{mg} \mathrm{chl}$. $\mathrm{gm}$ fresh weight, respectively while, the least values were gained from sandy medium without fertilization whether irrigated every 5 days in the first season or every 15 days in the second one as they gave the same value of $0.20 \mathrm{mg} \mathrm{chl}$. $/ \mathrm{gm}$ fresh weight. However, nitrogen is one of the essential nutrients which improve plant growth. It plays an important role in increasing chlorophyll since it is an important part of its structure (Devlin, 1975).

Generally this study recommends planting Conocarpus erectus (button wood) transplants in Dakahlia region either in clayey or clay + sand mixture $(1: 1)$ using the irrigation intervals of 10 or 15 days with adding of 5 or $10 \mathrm{gm} \mathrm{NPK/plant} \mathrm{to} \mathrm{gain} \mathrm{the} \mathrm{best} \mathrm{results} \mathrm{of} \mathrm{vegetative} \mathrm{growth.}$

\section{REFERENCES}

Atta - Alla, H. K. (2003). Effect of different growing media and fertilization on the vegetative growth, flowering and chemical composition of Cineraria (Senecio cruentus) plants. Alex. J. Agric - Res.; 48 (2): 101-114.

Brown, K. R. and R. Van den Driessche (2002). Growth and nutrition of hybrid poplars over 3 years after fertilization at planting. Can. J. For. Res., 32: $226-232$.

Devlin, R. M. (1975). Plant Physiology. 3rd Ed. Affiliated East - West Press Pvt. Ltd. New Delhi.

Gilman, E. F. and D. G. Watson. (1993). Conocarpus erectus, buttonwood. Fact Sheet ST- 179. U. S. Forest Service and Southern Group of State Foresters, Gainesville, FI. 3p.

Howard, R. A. (1989). Flora of the Lesser Antilles, Leeward and Windward Islands. Vol. 5. Arnold Arboretum, Harvard University, Jamaica Plain, MA. 604 P.

Jackson, M. L. (1967). "Soil Chemical Analysis". Printice - Hall of India, New Delhi.

Jasbir, S.; K. Barua and N. Das (2006). Integrated nutrient management for sustainable rice production in degraded shifting cultivation soil of Assam. Inter. J. Agric. Sci. hind Agric. Soc; Muzaffarnagar, India 2 (1): 186-189. 
Liogier, H. A. (1990). Plantas medicinales de Puerto Rico y del Caribe. Iberoamericana de Ediciones, Inc., San Juan, PR 566 pp.

Little, E. L. and F. H. Wadsworlh. (1964). Common Trees of Puerto Rico and the Virgin Islands. Agriculture Hand book 249. U. S. Department of Agriculture, Forest Service, Washington, DC. 548 pp.

Moran, R. (1982). "Formula for determination of chlorophyllous pigment extracted with N, N - dimethyl - formamid". Plant Physiol., 69: / 376 81.

Piper, C. S. (1950). Soil and Plant Analysis. Univ. Adelaide, Australia.

Pritchett, W. L., and R. F. Fisher (1987). Properties and Management of Forested Soils. 2nd ed. New York: John Wiley and Sons.

Richard, L. A. (1954). Diagnosis and Improvement of Saline and Alkali Soils. Handbook No. 60 Washington, D. C. US. Department of Agriculture.

Snedecor, G. W. and W. G. Cochran (1980). Statistical Methods. Lowa State Univ., Press Ames; Lowa, USA, 7th Ed.




Table (2): Interaction effects of soil type, irrigation intervals and NPK fertilizer rates on plant height (cm) of Conocarpus erectus during 2005 season

\begin{tabular}{|c|c|c|c|c|c|c|c|c|c|c|c|c|c|}
\hline \multirow{4}{*}{$\begin{array}{l}\text { Soil } \\
\text { type } \\
\text { (A) }\end{array}$} & \multirow{4}{*}{$\begin{array}{l}\text { Irrigation } \\
\text { intervals } \\
\text { (B) }\end{array}$} & \multirow{2}{*}{\multicolumn{4}{|c|}{ April }} & \multirow{2}{*}{\multicolumn{4}{|c|}{ July }} & \multirow{2}{*}{\multicolumn{4}{|c|}{ October }} \\
\hline & & & & & & & & & & & & & \\
\hline & & \multicolumn{3}{|c|}{$\begin{array}{l}\text { NPK (gm/plant) } \\
\text { (C) }\end{array}$} & \multirow{2}{*}{$\begin{array}{l}\text { Mean of } \\
(\mathrm{AXB})\end{array}$} & \multicolumn{3}{|c|}{$\begin{array}{l}\text { NPK (gm/plant) } \\
\text { (C) }\end{array}$} & \multirow{2}{*}{$\begin{array}{l}\text { Mean of } \\
\text { (AXB) }\end{array}$} & \multicolumn{3}{|c|}{$\begin{array}{l}\text { NPK (gm/plant) } \\
\text { (C) }\end{array}$} & \multirow{2}{*}{$\begin{array}{l}\text { Mean of } \\
\text { (AXB) }\end{array}$} \\
\hline & & 0.0 & 5.0 & 10.0 & & 0.0 & 5.0 & 10.0 & & 0.0 & 5.0 & 10.0 & \\
\hline \multirow{3}{*}{ Sandy } & 5 & 25.67 & 30.00 & 49.67 & 33.44 & 45.00 & 48.00 & 86.67 & 59.89 & 59.67 & 75.00 & 154.00 & 96.22 \\
\hline & 10 & 33.33 & 37.33 & 47.00 & 39.22 & 52.00 & 77.00 & 100.67 & 76.56 & 68.00 & 87.00 & 170.00 & 108.33 \\
\hline & 15 & 33.67 & 39.67 & 34.67 & 36.00 & 63.00 & 80.00 & 91.00 & 78.00 & 90.00 & 126.33 & 132.00 & 116.11 \\
\hline \multicolumn{2}{|c|}{ Mean of (AXC) } & 30.89 & 35.67 & 42.11 & & 53.33 & 68.33 & 92.78 & & 75.56 & 96.11 & 152.00 & \\
\hline \multirow{3}{*}{ Clayey } & 5 & 25.67 & 48.00 & 40.67 & 38.11 & 60.00 & 120.00 & 116.00 & 98.67 & 140.67 & 188.33 & 165.00 & 164.67 \\
\hline & 10 & 48.33 & 56.67 & 59.67 & 54.89 & 77.00 & 123.00 & 120.33 & 106.78 & 162.67 & 211.67 & 205.67 & 193.33 \\
\hline & 15 & 40.56 & 55.00 & 51.89 & 54.44 & 49.33 & 135.00 & 133.00 & 120.78 & 171.33 & 224.67 & 200.33 & 198.78 \\
\hline \multicolumn{2}{|c|}{ Mean of (AXC) } & 40.56 & 55.00 & 51.89 & & 77.11 & 126.00 & 123.11 & & 158.22 & 208.22 & 190.33 & \\
\hline \multirow{3}{*}{$\begin{array}{c}\text { Sand } \\
+ \\
\text { clay }\end{array}$} & 5 & 25.00 & 48.33 & 42.00 & 38.44 & 46.00 & 118.00 & 119.00 & 94.33 & 102.67 & 171.33 & 168.33 & 147.44 \\
\hline & 10 & 44.67 & 59.33 & 42.00 & 48.67 & 78.00 & 118.00 & 112.00 & 102.67 & 155.33 & 203.00 & 195.00 & 184.44 \\
\hline & 15 & 44.33 & 46.67 & 55.33 & 48.78 & 80.00 & 100.00 & 105.00 & 95.00 & 154.33 & 174.00 & 187.33 & 171.89 \\
\hline \multicolumn{2}{|c|}{ Mean of (AXC) } & 38.00 & 51.44 & 46.44 & \multirow{4}{*}{\begin{tabular}{cr}
\multicolumn{2}{c}{ L.S.D } \\
AB \\
AB & 1.25 \\
AC & 1.64 \\
BC & 1.64 \\
ABC & 2.01
\end{tabular}} & 68.00 & 112.00 & 112.00 & \multirow{4}{*}{\begin{tabular}{ll}
\multicolumn{2}{c}{ L.S.D $5 \%$} \\
AB & 1.51 \\
AC & 1.99 \\
BC & 1.99 \\
ABC & 2.43
\end{tabular}} & 137.44 & 182.78 & 183.56 & \multirow{4}{*}{$\begin{array}{lr}\text { L.S.D } 5 \% \\
\text { AB } & 1.52 \\
\text { AC } & 2.00 \\
\text { BC } & 2.00 \\
\text { ABC } & 2.44\end{array}$} \\
\hline \multirow{3}{*}{$\begin{array}{l}\text { Mean } \\
(\mathrm{BXC})\end{array}$} & 5 & 26.89 & 40.67 & 42.44 & & 50.33 & 95.33 & 107.22 & & 106.11 & 139.78 & 162.44 & \\
\hline & 10 & 42.11 & 51.11 & 49.56 & & 69.00 & 106.00 & 111.00 & & 128.67 & 167.22 & 190.22 & \\
\hline & 15 & 41.89 & 48.89 & 48.44 & & 84.78 & 99.33 & 109.67 & & 150.67 & 162.89 & 173.22 & \\
\hline
\end{tabular}


Table (3): Interaction effects of soil type, irrigation intervals and NPK fertilizer rates on plant height (cm) of Conocarpus erectus during 2006 season

\begin{tabular}{|c|c|c|c|c|c|c|c|c|c|c|c|c|c|}
\hline \multirow{3}{*}{$\begin{array}{l}\text { Soil } \\
\text { type } \\
\text { (A) }\end{array}$} & \multirow{3}{*}{$\begin{array}{l}\text { Irrigation } \\
\text { intervals } \\
\text { (B) }\end{array}$} & \multicolumn{4}{|c|}{ April } & \multicolumn{4}{|c|}{ July } & \multicolumn{4}{|c|}{ October } \\
\hline & & \multicolumn{3}{|c|}{$\begin{array}{l}\text { NPK (gm/plant) } \\
\text { (C) }\end{array}$} & \multirow{2}{*}{$\begin{array}{l}\text { Mean of } \\
\text { (AXB) }\end{array}$} & \multicolumn{3}{|c|}{$\begin{array}{l}\text { NPK (gm/plant) } \\
\text { (C) }\end{array}$} & \multirow{2}{*}{$\begin{array}{l}\text { Mean of } \\
\text { (AXB) }\end{array}$} & \multicolumn{3}{|c|}{$\begin{array}{l}\text { NPK (gm/plant) } \\
\text { (C) }\end{array}$} & \multirow{2}{*}{$\begin{array}{l}\text { Mean of } \\
\text { (AXB) }\end{array}$} \\
\hline & & 0.0 & 5.0 & 10.0 & & 0.0 & 5.0 & 10.0 & & 0.0 & 5.0 & 10.0 & \\
\hline \multirow{3}{*}{ Sandy } & 5 & 20.33 & 32.33 & 42.67 & 31.78 & 39.33 & 55.00 & 84.67 & 59.67 & 73.33 & 74.00 & 150.00 & 99.11 \\
\hline & 10 & 34.67 & 40.67 & 52.67 & 42.67 & 53.00 & 86.00 & 106.33 & 81.78 & 65.67 & 102.33 & 173.67 & 113.89 \\
\hline & 15 & 35.20 & 42.33 & 43.67 & 40.40 & 63.67 & 67.67 & 87.67 & 73.00 & 100.00 & 106.67 & 136.33 & 114.33 \\
\hline \multicolumn{2}{|c|}{ Mean of (AXC) } & 30.07 & 38.44 & 46.34 & & 52.00 & 69.59 & 92.89 & & 79.67 & 94.33 & 153.33 & \\
\hline \multirow{3}{*}{ Clayey } & 5 & 24.00 & 52.00 & 42.00 & 39.33 & 57.67 & 125.33 & 107.67 & 96.89 & 145.00 & 188.67 & 145.33 & 159.56 \\
\hline & 10 & 49.33 & 51.33 & 64.33 & 55.00 & 85.33 & 121.67 & 124.00 & 110.33 & 147.33 & 203.67 & 200.33 & 183.78 \\
\hline & 15 & 53.67 & 63.67 & 52.67 & 56.67 & 99.33 & 137.67 & 138.67 & 125.22 & 183.67 & 205.33 & 191.67 & 193.56 \\
\hline \multicolumn{2}{|c|}{ Mean of (AXC) } & 42.33 & 55.67 & 53.00 & & 80.78 & 128.22 & 123.44 & & 158.67 & 199.22 & 179.00 & \\
\hline \multirow{3}{*}{$\begin{array}{c}\text { Sand } \\
+ \\
\text { clay }\end{array}$} & 5 & 21.67 & 58.67 & 31.33 & 37.22 & 41.00 & 110.33 & 113.00 & 88.11 & 88.67 & 160.67 & 164.67 & 138.00 \\
\hline & 10 & 41.00 & 64.00 & 44.00 & 49.67 & 75.67 & 123.00 & 111.67 & 103.44 & 150.00 & 199.00 & 193.33 & 180.78 \\
\hline & 15 & 50.67 & 57.00 & 64.33 & 57.33 & 78.33 & 99.00 & 100.67 & 92.67 & 146.33 & 169.67 & 190.00 & 168.67 \\
\hline \multicolumn{2}{|c|}{ Mean of (AXC) } & 37.78 & 59.89 & 46.56 & \multirow{4}{*}{$\begin{array}{cc}\text { L.S.D } & 5 \% \\
\text { AB } & 1.38 \\
\text { AC } & 1.81 \\
\text { BC } & 1.81 \\
\text { ABC } & 2.21\end{array}$} & 65.00 & 110.78 & & \multirow{4}{*}{\begin{tabular}{cc}
\multicolumn{2}{c}{ L.S.D 5\% } \\
AB & 1.89 \\
AC & 2.49 \\
BC & 2.49 \\
ABC & 3.04
\end{tabular}} & 128.33 & 176.44 & 182.67 & \multirow{4}{*}{$\begin{array}{cc}\text { L.S.D } & 5 \% \\
\text { AB } & 1.69 \\
\text { AC } & 2.22 \\
\text { BC } & 2.22 \\
\text { ABC } & 2.71\end{array}$} \\
\hline \multirow{3}{*}{$\begin{array}{l}\text { Mean } \\
(B \times C)\end{array}$} & 5 & 22.00 & 47.67 & 38.67 & & 46.00 & 96.89 & 101.78 & & 102.56 & 140.89 & 153.22 & \\
\hline & 10 & 41.67 & 52.00 & 53.67 & & 71.33 & 110.22 & 114.00 & & 121.00 & 168.33 & 189.11 & \\
\hline & 15 & 48.89 & 54.78 & 48.67 & & 88.44 & 101.44 & 101.00 & & 155.44 & 158.33 & 162.78 & \\
\hline
\end{tabular}


Table (5): Interaction effects of soil type, irrigation intervals and NPK fertilizer rates on number of branches per plant of Conocarpus erectus during 2005 season

\begin{tabular}{|c|c|c|c|c|c|c|c|c|c|c|c|c|c|}
\hline \multirow{3}{*}{$\begin{array}{l}\text { Soil type } \\
\text { (A) }\end{array}$} & \multirow{3}{*}{$\begin{array}{l}\text { Irrigation } \\
\text { intervals } \\
\text { (B) }\end{array}$} & \multicolumn{4}{|c|}{ April } & \multicolumn{4}{|c|}{ July } & \multicolumn{4}{|c|}{ October } \\
\hline & & \multicolumn{3}{|c|}{$\begin{array}{c}\text { NPK (gm/plant) } \\
\text { (C) }\end{array}$} & \multirow{2}{*}{$\begin{array}{l}\text { Mean of } \\
\text { (AXB) }\end{array}$} & \multicolumn{3}{|c|}{ NPK (gm/plant) } & \multirow{2}{*}{$\begin{array}{l}\text { Mean of } \\
\text { (AXB) }\end{array}$} & \multicolumn{3}{|c|}{$\begin{array}{l}\text { NPK (gm/plant) } \\
\text { (C) }\end{array}$} & \multirow{2}{*}{$\begin{array}{l}\text { Mean of } \\
\text { (AXB) }\end{array}$} \\
\hline & & 0.0 & 5.0 & 10.0 & & 0.0 & 5.0 & 10.0 & & 0.0 & 5.0 & 10.0 & \\
\hline \multirow{3}{*}{ Sandy } & 5 & 6.67 & 8.33 & 15.33 & 10.11 & 15.67 & 18.33 & 25.00 & 19.67 & 27.67 & 28.67 & 52.67 & 36.33 \\
\hline & 10 & 13.00 & 14.33 & 16.33 & 14.56 & 22.00 & 29.00 & 34.33 & 28.44 & 34.00 & 43.33 & 58.00 & 45.11 \\
\hline & 15 & 14.33 & 16.67 & 17.33 & 16.11 & 24.67 & 33.67 & 33.33 & 30.56 & 33.00 & 48.67 & 47.00 & 42.89 \\
\hline \multicolumn{2}{|c|}{ Mean of (AXC) } & 11.33 & 13.11 & 16.33 & & 20.78 & 27.00 & 30.89 & & 31.56 & 40.22 & 52.56 & \\
\hline \multirow{3}{*}{ Clayey } & 5 & 6.00 & 16.00 & 13.00 & 11.67 & 18.33 & 39.33 & 39.00 & 32.22 & 35.33 & 57.67 & 52.33 & 48.44 \\
\hline & 10 & 14.67 & 20.00 & 19.33 & 18.00 & 30.00 & 41.67 & 37.00 & 36.22 & 52.67 & 71.00 & 64.67 & 62.78 \\
\hline & 15 & 17.67 & 17.33 & 18.67 & 17.89 & 31.67 & 41.33 & 35.67 & 36.22 & 52.33 & 56.00 & 61.33 & 56.56 \\
\hline \multicolumn{2}{|c|}{ Mean of (AXC) } & 12.78 & 17.78 & 17.00 & & 26.67 & 40.78 & 37.22 & & 46.78 & 61.56 & 59.44 & \\
\hline \multirow{3}{*}{$\begin{array}{c}\text { Sand } \\
+ \\
\text { clay }\end{array}$} & 5 & 6.33 & 16.67 & 11.67 & 11.56 & 20.00 & 35.33 & 38.33 & 31.22 & 47.00 & 62.33 & 55.00 & 54.78 \\
\hline & 10 & 17.33 & 20.33 & 20.67 & 19.44 & 27.00 & 38.33 & 39.33 & 34.89 & 58.33 & 78.33 & 70.00 & 68.22 \\
\hline & 15 & 17.33 & 21.00 & 18.00 & 18.78 & 34.33 & 45.00 & 45.33 & 41.56 & 52.67 & 76.33 & 67.33 & 65.44 \\
\hline \multicolumn{2}{|c|}{ Mean of (AXC) } & 13.67 & 19.33 & 16.78 & \multirow{4}{*}{\begin{tabular}{cc}
\multicolumn{2}{c}{ L.S.D $5 \%$} \\
AB & 0.88 \\
AC & 1.15 \\
BC & 1.15 \\
ABC & 1.14
\end{tabular}} & 27.11 & 39.56 & 41.00 & \multirow{4}{*}{\begin{tabular}{|cc}
\multicolumn{2}{|c}{ L.S.D $5 \%$} \\
AB & 1.07 \\
AC & 1.41 \\
BC & 1.41 \\
ABC & 1.72
\end{tabular}} & 52.67 & 71.67 & 64.11 & \multirow{4}{*}{\begin{tabular}{cc}
\multicolumn{2}{|c}{ L.S.D $5 \%$} \\
AB & 1.07 \\
AC & 1.41 \\
BC & 1.41 \\
ABC & 1.72
\end{tabular}} \\
\hline \multirow{3}{*}{$\begin{array}{l}\text { Mean } \\
\text { (BXC) }\end{array}$} & 5 & 6.89 & 13.11 & 13.33 & & 18.89 & 30.11 & 34.11 & & 37.00 & 44.22 & 53.33 & \\
\hline & 10 & 16.11 & 17.78 & 18.11 & & 26.33 & 36.33 & 36.89 & & 48.33 & 63.56 & 64.22 & \\
\hline & 15 & 17.44 & 18.33 & 17.00 & & 33.22 & 37.00 & 38.11 & & 51.21 & 55.11 & 58.56 & \\
\hline
\end{tabular}


Table (6): Interaction effects of soil type, irrigation intervals and NPK fertilizer rates on number of branches per plant of Conocarpus erectus during 2006 season

\begin{tabular}{|c|c|c|c|c|c|c|c|c|c|c|c|c|c|}
\hline \multirow{3}{*}{$\begin{array}{c}\text { Soil } \\
\text { Type } \\
\text { (A) }\end{array}$} & \multirow{3}{*}{$\begin{array}{l}\text { Irrigation } \\
\text { intervals } \\
\text { (B) }\end{array}$} & \multicolumn{4}{|c|}{ April } & \multicolumn{4}{|c|}{ July } & \multicolumn{4}{|c|}{ October } \\
\hline & & \multicolumn{3}{|c|}{$\begin{array}{l}\text { NPK (gm/plant) } \\
\text { (C) }\end{array}$} & \multirow{2}{*}{ Mean of (AXB) } & \multicolumn{3}{|c|}{$\begin{array}{l}\text { NPK (gm/plant) } \\
\text { (C) }\end{array}$} & \multirow{2}{*}{ Mean of (AXB) } & \multicolumn{3}{|c|}{$\begin{array}{l}\text { NPK (gm/plant) } \\
\text { (C) }\end{array}$} & \multirow{2}{*}{ Mean of (AXB) } \\
\hline & & 0.0 & 5.0 & 10.0 & & 0.0 & 5.0 & 10.0 & & 0.0 & 5.0 & 10.0 & \\
\hline \multirow{3}{*}{ Sandy } & 5 & 6.00 & 6.33 & 17.67 & 10.00 & 13.00 & 14.67 & 27.67 & 18.44 & 21.33 & 24.00 & 51.33 & 32.22 \\
\hline & 10 & 12.67 & 15.00 & 18.33 & 15.33 & 28.00 & 31.00 & 33.67 & 30.89 & 39.00 & 42.00 & 53.00 & 44.67 \\
\hline & 15 & 14.67 & 18.33 & 20.00 & 17.67 & 22.00 & 34.00 & 34.33 & 30.11 & 32.67 & 47.00 & 51.00 & 43.56 \\
\hline \multicolumn{2}{|c|}{ Mean of (AXC) } & 11.11 & 13.22 & 18.67 & & 21.00 & 26.56 & 31.89 & & 31.00 & 37.67 & 51.78 & \\
\hline \multirow{3}{*}{ Clayey } & 5 & 6.00 & 16.33 & 16.33 & 12.89 & 14.00 & 43.33 & 42.67 & 35.00 & 37.33 & 59.33 & 57.33 & 51.33 \\
\hline & 10 & 16.67 & 23.67 & 18.00 & 14.44 & 38.00 & 45.67 & 42.33 & 42.00 & 54.00 & 73.67 & 68.67 & 65.44 \\
\hline & 15 & 16.67 & 18.33 & 21.00 & 18.67 & 33.67 & 39.67 & 40.00 & 37.78 & 44.33 & 47.00 & 69.00 & 53.44 \\
\hline \multicolumn{2}{|c|}{ Mean of (AXC) } & 13.11 & 14.44 & 18.44 & & 30.22 & 42.89 & 41.67 & & 45.22 & 60.00 & 65.00 & \\
\hline \multirow{3}{*}{$\begin{array}{c}\text { Sand } \\
+ \\
\text { clay }\end{array}$} & 5 & 6.00 & 18.67 & 10.00 & 11.56 & 16.00 & 36.00 & 35.67 & 29.22 & 33.00 & 67.00 & 58.00 & 52.67 \\
\hline & 10 & 20.00 & 20.33 & 20.67 & 20.33 & 29.67 & 42.00 & 44.00 & 38.56 & 61.33 & 82.33 & 63.67 & 69.11 \\
\hline & 15 & 20.00 & 20.33 & 16.67 & 20.00 & 35.00 & 50.33 & 43.00 & 42.78 & 57.00 & 89.67 & 66.0 & 70.89 \\
\hline \multicolumn{2}{|c|}{ Mean of (AXC) } & 15.33 & 20.78 & 15.78 & \multirow{4}{*}{\begin{tabular}{ll}
\multicolumn{2}{c}{ L.S.D $5 \%$} \\
AB & 0.94 \\
AC & 1.24 \\
BC & 1.24 \\
ABC & 1.51
\end{tabular}} & 26.89 & 42.78 & 40.89 & \multirow{4}{*}{$\begin{array}{|cc|}\text { L.S.D } & 5 \% \\
\text { AB } & 1.02 \\
\text { AC } & 1.34 \\
\text { BC } & 1.34 \\
\text { ABC } & 1.64 \\
\end{array}$} & 50.44 & 79.67 & 62.56 & \multirow{4}{*}{\begin{tabular}{|cc} 
L.S.D $5 \%$ \\
AB & 1.10 \\
AC & 1.45 \\
BC & 1.45 \\
ABC & 1.77
\end{tabular}} \\
\hline \multirow{3}{*}{ Mean (BXC) } & 5 & 6.11 & 13.67 & 14.67 & & 16.56 & 30.78 & 35.33 & & 31.44 & 49.22 & 55.56 & \\
\hline & 10 & 18.33 & 19.67 & 17.11 & & 31.89 & 39.56 & 40.00 & & 51.44 & 66.00 & 61.78 & \\
\hline & 15 & 18.89 & 20.00 & 17.44 & & 34.22 & 37.33 & 39.11 & & 50.78 & 56.44 & 60.67 & \\
\hline
\end{tabular}


Table (8): Interaction effects of soil type, irrigation intervals and NPK fertilizer rates on stem diameter (mm) of Conocarpus erectus during 2005

\begin{tabular}{|c|c|c|c|c|c|c|c|c|c|c|c|c|c|}
\hline \multirow{4}{*}{$\begin{array}{l}\text { Soil } \\
\text { type } \\
\text { (A) }\end{array}$} & \multirow{4}{*}{$\begin{array}{l}\text { Irrigation } \\
\text { intervals } \\
\text { (B) }\end{array}$} & \multirow{2}{*}{\multicolumn{4}{|c|}{ April }} & \multirow{2}{*}{\multicolumn{4}{|c|}{ July }} & \multirow{2}{*}{\multicolumn{4}{|c|}{ October }} \\
\hline & & & & & & & & & & & & & \\
\hline & & \multicolumn{3}{|c|}{$\begin{array}{l}\text { NPK (gm/plant) } \\
\text { (C) }\end{array}$} & \multirow{2}{*}{$\begin{array}{c}\text { Mean of } \\
(\mathrm{AXB})\end{array}$} & \multicolumn{3}{|c|}{$\begin{array}{l}\text { NPK (gm/plant) } \\
\text { (C) }\end{array}$} & \multirow{2}{*}{$\begin{array}{l}\text { Mean of } \\
\text { (AXB) }\end{array}$} & \multicolumn{3}{|c|}{$\begin{array}{l}\text { NPK (gm/plant) } \\
\text { (C) }\end{array}$} & \multirow{2}{*}{$\begin{array}{c}\text { Mean of } \\
(\mathrm{AXB})\end{array}$} \\
\hline & & 0.0 & 5.0 & 10.0 & & 0.0 & 5.0 & 10.0 & & 0.0 & 5.0 & 10.0 & \\
\hline \multirow{3}{*}{ Sandy } & 5 & 2.47 & 2.73 & 3.57 & 2.92 & 3.70 & 4.07 & 8.23 & 5.33 & 5.63 & 6.93 & 21.27 & 11.28 \\
\hline & 10 & 3.10 & 3.63 & 4.60 & 3.77 & 5.80 & 7.87 & 11.67 & 8.44 & 8.23 & 12.80 & 25.07 & 15.37 \\
\hline & 15 & 3.13 & 4.33 & 4.30 & 3.92 & 6.53 & 9.00 & 11.67 & 9.07 & 10.87 & 17.50 & 17.67 & 15.43 \\
\hline \multicolumn{2}{|c|}{ Mean of (AXC) } & 2.90 & 3.56 & 4.16 & & 5.34 & 6.98 & 10.52 & & 8.24 & 12.41 & 21.34 & \\
\hline \multirow{3}{*}{ Clayey } & 5 & 2.40 & 3.73 & 3.23 & 3.12 & 4.73 & 10.37 & 8.97 & 8.02 & 16.17 & 23.33 & 23.23 & 20.91 \\
\hline & 10 & 4.23 & 5.13 & 5.20 & 4.86 & 7.50 & 14.13 & 12.00 & 11.21 & 24.30 & 28.30 & 25.63 & 26.08 \\
\hline & 15 & 3.83 & 6.10 & 5.00 & 4.97 & 10.53 & 19.23 & 18.40 & 16.06 & 24.60 & 35.37 & 26.97 & 28.98 \\
\hline \multicolumn{2}{|c|}{ Mean of (AXC) } & 3.49 & 4.98 & 4.48 & & 7.95 & 14.58 & 13.12 & & 21.69 & 29.00 & 25.28 & \\
\hline \multirow{3}{*}{$\begin{array}{c}\text { Sand } \\
+ \\
\text { Clay }\end{array}$} & 5 & 2.17 & 3.70 & 3.53 & 3.13 & 4.07 & 11.30 & 10.23 & 8.53 & 11.97 & 22.97 & 23.13 & 19.36 \\
\hline & 10 & 4.30 & 5.97 & 4.10 & 4.79 & 7.57 & 12.67 & 12.13 & 10.79 & 24.33 & 26.87 & 26.70 & 25.97 \\
\hline & 15 & 4.27 & 5.43 & 5.63 & 5.11 & 8.63 & 10.60 & 11.97 & 10.40 & 23.70 & 25.67 & 25.47 & 24.94 \\
\hline \multicolumn{2}{|c|}{ Mean of (AXC) } & 3.58 & 5.03 & 4.42 & \multirow{4}{*}{$\begin{array}{cc}\text { L.S.D } & 5 \% \\
\text { AB } & 1.25 \\
\text { AC } & 1.64 \\
\text { BC } & 1.64 \\
\text { ABC } & 2.01\end{array}$} & 6.76 & 11.52 & 11.44 & \multirow{4}{*}{$\begin{array}{cc}\text { L.S.D } & 5 \% \\
\text { AB } & 1.25 \\
\text { AC } & 1.64 \\
\text { BC } & 1.64 \\
\text { ABC } & 2.01\end{array}$} & 20.00 & 25.17 & 25.10 & \multirow{4}{*}{\begin{tabular}{cc}
\multicolumn{2}{c}{ L.S.D $5 \%$} \\
AB & 0.84 \\
AC & 1.10 \\
BC & 1.10 \\
ABC & 1.35 \\
\end{tabular}} \\
\hline \multirow{3}{*}{$\begin{array}{l}\text { Mean } \\
\text { (BXC) }\end{array}$} & 5 & 2.43 & 3.30 & 3.44 & & 4.17 & 8.58 & 9.14 & & 11.69 & 17.31 & 22.54 & \\
\hline & 10 & 3.87 & 4.91 & 4.63 & & 6.96 & 11.56 & 11.93 & & 18.96 & 22.66 & 25.80 & \\
\hline & 15 & 3.74 & 5.28 & 4.98 & & 9.39 & 12.12 & 14.01 & & 21.93 & 23.97 & 23.37 & \\
\hline
\end{tabular}


Table (9): Interaction effects of soil type, irrigation intervals and NPK fertilizer rates on stem diameter (mm) of Conocarpus erectus during 2006

\begin{tabular}{|c|c|c|c|c|c|c|c|c|c|c|c|c|c|}
\hline \multirow{4}{*}{$\begin{array}{l}\text { Soil } \\
\text { type } \\
\text { (A) }\end{array}$} & \multirow{4}{*}{$\begin{array}{l}\text { Irrigation } \\
\text { intervals } \\
\text { (B) }\end{array}$} & \multirow{2}{*}{\multicolumn{4}{|c|}{ April }} & \multirow{2}{*}{\multicolumn{4}{|c|}{ July }} & \multirow{2}{*}{\multicolumn{4}{|c|}{ October }} \\
\hline & & & & & & & & & & & & & \\
\hline & & \multicolumn{3}{|c|}{$\begin{array}{l}\text { NPK (gm/plant) } \\
\text { (C) }\end{array}$} & \multirow{2}{*}{$\begin{array}{l}\text { Mean of } \\
\text { (AXB) }\end{array}$} & \multicolumn{3}{|c|}{$\begin{array}{l}\text { NPK (gm/plant) } \\
\text { (C) }\end{array}$} & \multirow{2}{*}{$\begin{array}{l}\text { Mean of } \\
\text { (AXB) }\end{array}$} & \multicolumn{3}{|c|}{$\begin{array}{c}\text { NPK (gm/plant) } \\
\text { (C) }\end{array}$} & \multirow{2}{*}{$\begin{array}{l}\text { Mean of } \\
\text { (AXB) }\end{array}$} \\
\hline & & 0.0 & 5.0 & 10.0 & & 0.0 & $\begin{array}{l}(v) \\
5.0\end{array}$ & 10.0 & & 0.0 & 5.0 & 10.0 & \\
\hline \multirow{3}{*}{ Sandy } & 5 & 2.27 & 2.63 & 3.47 & 2.79 & 3.40 & 4.23 & 8.23 & 5.29 & 6.07 & 7.57 & 20.60 & 11.41 \\
\hline & 10 & 3.17 & 3.54 & 5.45 & 4.06 & 6.60 & 8.17 & 12.03 & 8.93 & 9.37 & 13.57 & 23.57 & 15.50 \\
\hline & 15 & 3.56 & 5.09 & 4.10 & 4.25 & 7.23 & 9.43 & 12.63 & 9.77 & 10.53 & 17.40 & 17.30 & 15.08 \\
\hline \multicolumn{2}{|c|}{ Mean of (AXC) } & 3.00 & 3.76 & 4.34 & & 5.74 & 7.28 & 10.96 & & 8.66 & 12.85 & 20.49 & \\
\hline \multirow{3}{*}{ Clayey } & 5 & 2.42 & 3.13 & 3.40 & 2.98 & 5.00 & 10.90 & 10.10 & 8.67 & 15.13 & 24.07 & 25.43 & 21.54 \\
\hline & 10 & 4.70 & 5.10 & 6.41 & 5.40 & 8.50 & 14.67 & 12.57 & 11.91 & 26.13 & 31.37 & 29.27 & 28.92 \\
\hline & 15 & 4.13 & 7.24 & 5.53 & 5.63 & 11.80 & 21.10 & 18.80 & 17.23 & 28.17 & 40.63 & 23.87 & 30.89 \\
\hline \multicolumn{2}{|c|}{ Mean of (AXC) } & 3.75 & 5.16 & 5.11 & & 8.43 & 15.56 & 13.82 & & 23.14 & 32.02 & 26.19 & \\
\hline \multirow{3}{*}{$\begin{array}{c}\text { Sand } \\
+ \\
\text { Clay }\end{array}$} & 5 & 2.70 & 3.96 & 4.31 & 3.66 & 4.67 & 12.30 & 11.27 & 9.41 & 12.13 & 23.90 & 24.77 & 20.27 \\
\hline & 10 & 4.43 & 4.29 & 5.27 & 4.66 & 7.83 & 11.53 & 14.00 & 11.12 & 25.37 & 27.30 & 28.17 & 26.94 \\
\hline & 15 & 4.57 & 6.47 & 5.36 & 5.46 & 10.47 & 11.37 & 11.00 & 10.94 & 26.13 & 25.60 & 26.30 & 26.01 \\
\hline \multicolumn{2}{|c|}{ Mean of (AXC) } & 3.89 & 4.91 & 4.98 & \multirow{4}{*}{$\begin{array}{ll}\text { L.S.D } & 5 \% \\
\text { AB } & 0.45 \\
\text { AC } & 0.59 \\
\text { BC } & 0.59 \\
\text { ABC } & 0.72\end{array}$} & 7.66 & 11.73 & 12.09 & \multirow{4}{*}{$\begin{array}{ll}\text { L.S.D } & 5 \% \\
\text { AB } & 0.63 \\
\text { AC } & 0.83 \\
\text { BC } & 0.83 \\
\text { ABC } & 1.01\end{array}$} & 21.21 & 25.06 & 26.41 & \multirow{4}{*}{\begin{tabular}{ll}
\multicolumn{2}{c}{ L.S.D $5 \%$} \\
AB & 0.77 \\
AC & 1.02 \\
BC & 1.02 \\
ABC & 1.24
\end{tabular}} \\
\hline \multirow{3}{*}{$\begin{array}{l}\text { Mean } \\
\text { (BXC) }\end{array}$} & 5 & 2.46 & 3.24 & 3.72 & & 4.36 & 9.14 & 9.87 & & 11.61 & 18.01 & 23.60 & \\
\hline & 10 & 4.10 & 4.31 & 5.71 & & 7.64 & 11.46 & 12.87 & & 20.29 & 24.08 & 27.00 & \\
\hline & 15 & 4.08 & 6.26 & 5.00 & & 10.57 & 13.23 & 14.14 & & 23.90 & 25.59 & 22.49 & \\
\hline
\end{tabular}


